\title{
A Study of Somaclonal Variation for Rice Improvement Induced by Three Kinds of Anther-derived Cell Culture Techniques
}

\author{
Toshiya Yamamoto, Yasutaka SoEdA, Akira NishiKawA \\ and Hideo HiroHara \\ Takarazuka Research Center, Sumitomo Chemical Co., Ltd., \\ Takarazuka, Hyogo 665, Japan
}

(Received September 22, 1993)

(Accepted April 30, 1994)

\begin{abstract}
Somaclonal variation in rice induced in three kinds of anther-derived cell culture was morphologically studied. The three kinds of anther-derived cell cultures were the newly developed one-step short-term anther culture, the conventional two-step anther culture, and the anther-derived protoplast culture. Both the tendency for higher ploidy of regenerants and the morphological variation of the A2 lines increased with increasing duration of culture in order of the one-step, the two-step and the protoplast cultures. Twenty two percent of the regenerants and $95 \%$ of the $\mathrm{A} 2$ were tetraploids and variants respectively, in the protoplast culture. No variation was, however, characteristic of protoplast culture, which caused multiple variations in characteristics with high frequency. All of the variations, which were mainly induced in the haploid callus, showed their specific tendencies such as shortening culm length, reducing hair, and delaying heading date. Protoplast-induced variations were concluded not to hinder obtaining useful transformants through protoplast. Both anther and protoplast cultures were found, for the first time, to be the most reliable method of breeding a glabrous rice variety which can be readily hulled and threshed by machine.
\end{abstract}

\section{Introduction}

It is recognized that somaclonal variation is a useful tool for rice improvement. Among various kinds of tissue and cell cultures, anther and protoplast cultures may be the two most effective techniques for obtaining somaclonal variation in rice. They often produce somaclonal variants with useful characteristics such as disease resistance, high yield and short plant height ${ }^{1,2}$. In fact, quite a few of the new varieties of rice have been produced by anther or protoplast culture techniques in Japan as well as China ${ }^{3-5}$. Contrary to the practical application, it is difficult to regulate the types and the frequency of variants to be induced in anther or protoplast cultures.

The first purpose of this study is, therefore, to examine variants so as to be able to predict the types and the frequency of somaclonal variation which will appear in A2 (the second) generation of regenerants from anther culture or protoplast culture. This will certainly make anther and protoplast cultures more useful techniques for rice improvement. In this connection, it would be very interesting if an undocumented type of useful variation could be found with considerably high frequency in A2.

The second is to examine whether variation increases with increasing duration of culture and whether there is any characteristic variation in the protoplast culture process. We should like to 
know what process in the cultures most influences variation in A2.

The third is to check whether somaclonal variation induced in the process of protoplast culture hinders the production of useful transformants through protoplast. This is also an important issue since protoplast culture is a basal technique for genetic engineering or cell fusion for the incorporation of a valuable gene(or genes) of a desired characteristic(s) into the rice plant.

To accomplish these purposes, we systematically study morphological somaclonal variations in A2 induced by the following three cell culture methods: (1) the newly developed one-step anther culture method ${ }^{6}$, (2) the conventional two-step anther culture method and(3) the anther-derived protoplast culture method.

\section{Materials and Methods}

\section{Plant materials and anther culture}

Plants of rice(Oryza sativa L. cv. 'Koganebare') were used in this study. The plants were grown in a paddy field to collect the panicles.

The one-step and the two-step anther cultures were carried out as described in detail ${ }^{6)}$.

\section{Protoplast culture}

Anther-derived calli induced by the conventional two-step anther culture method were transferred to a conical flask containing liquid AA medium ${ }^{7)}$ to establish suspension cultures. Liquid cultures were shaken at $100 \mathrm{rpm}$ under continuous dim light and were maintained by sub-culturing every two weeks. A one gram fresh weight aliquot of three- to five-day-old suspension-cultured cells was added to $20 \mathrm{~m} l$ enzyme solution consisting of $4 \%$ Cellulase RS (Yakult), 1\% Macerozyme

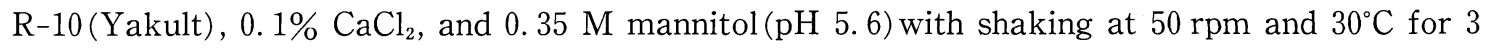
hours. The resulting suspension was then filtered through a $45-\mu \mathrm{m}$ mesh. After centrifugation at $150 \times \mathrm{g}$ for $3 \mathrm{~min}$., pelleted protoplasts were collected and washed three times with the $0.35 \mathrm{M}$ mannitol solution containing $0.1 \% \mathrm{CaCl}_{2}$.

Washed protoplasts were plated for callus formation at a density of $2-4 \times 10^{5} / \mathrm{m} l$ in liquid $\mathrm{R} 2^{8)}$ medium( $\mathrm{pH} 5.8$ ) containing $0.4 \mathrm{M}$ sucrose and $2 \mathrm{mg} / \mathrm{l} 2,4-\mathrm{D}$ for 40 days. Calli formed were transferred to solid R2 medium( $\mathrm{pH} 5.8$ ) containing $1 \%$ agarose, $6 \%$ sucrose and $2 \mathrm{mg} / \mathrm{l} 2,4-\mathrm{D}$ and cultured 2 to 3 weeks for further growth.

Calli of 1 to $2 \mathrm{~mm}$ in diameter were transferred to regeneration medium ( $\mathrm{pH} \mathrm{5.8)}$ containing $\mathrm{N} 6$ basal components ${ }^{9}, 1 \%$ agarose and $6 \%$ sucrose, or in addition, $1 \mathrm{mg} / l$ kinetin and $0.2 \mathrm{mg} / l \mathrm{IBA}$ (indolebutilic acid). Regenerated plantlets of 1 to $3 \mathrm{~cm}$ in height were transferred to test tubes containing the same medium for further growth. Plants of 10 to $15 \mathrm{~cm}$ in height were then planted in potted soils and grown to maturity in a greenhouse.

\section{Ploidy of regenerant}

Ploidies of regenerants were determined by observation of plants and chromosome number at root tips ${ }^{6}$.

\section{Determination of somaclonal variation}

Twenty four individuals in each line of A2 generation of diploid regenerants were grown in a paddy field. Somaclonal variation was investigated through observation of seed fertility, heading date, grain size, glume shape and awn length. Ten out of twenty-four individuals were measured for culm length, panicle length and panicle number. The results were compared with those of the original variety of 'Koganebare'. Somaclonal variants were confirmed by analysis of variance at $1 \%$ level.

Hairiness was determined by not only the feel of the leaf surface but also observation of glume 
hair with a microscope.

\section{Results and Discussion}

\section{Ploidy of regenerant}

The frequency of haploid regenerants drastically decreases with the order of the one-step anther, the two-step anther and the anther-derived protoplast cultures(Table 1). Tetraploid plants show a fairly high frequency (twice that of haploid) in the protoplast culture, and zero percent in the one -step culture(Table 1). A small number of aneuploid-like plants were detected only in the protoplast culture. It was, however, excluded from Table 1 because of ambiguity.

Since it takes about 1.5, 3 and 6 months to obtain regenerants in the one-step anther, the twostep anther and the protoplast cultures respectively, it is clear that the ploidy of regenerants increases with increasing duration of culture. Furthermore, spontaneous doublings of haploid and diploid are concluded to occur mainly in the processes of culturing anther-derived callus and of suspension culture to culturing protoplast, respectively.

\section{Type and frequency of somaclonal variation}

Table 2 summarizes the types and the frequency of somaclonal variation found in the lines of A2 generation of the regenerants from the one-step, the two-step and the protoplast cultures. Considering the purposes of this study, all of the A2 lines examined were obtained from the spontaneously doubled haploid plants, so that in the case of the one-step anther culture, a small

Table 1. Ploidy of regenerant.

\begin{tabular}{lccrrrrr}
\hline \multirow{2}{*}{ culture method } & plant regenerated & \multicolumn{2}{c}{ haploid } & \multicolumn{2}{c}{ diploid } & \multicolumn{2}{c}{ tetraploid } \\
& No. & No. & $\%$ & No. & $\%$ & No. & $\%$ \\
\hline one-step anther*1 & 62 & 44 & 71 & 18 & 29 & 0 & 0 \\
two-step anther*2 & 146 & 52 & 36 & 94 & 64 & $<10$ & $6-7$ \\
protoplast*3 & 169 & 18 & 11 & 114 & 67 & 37 & 22 \\
\hline
\end{tabular}

${ }^{* 1}$ Anthers were inoculated on the N6 hormone-free medium after hormone treatment.

*2 Anthers were inoculated on the $\mathrm{N} 6$ medium supplemented with $2.0 \mathrm{mg} / l 2,4-\mathrm{D}$ and $0.5 \mathrm{mg} / l \mathrm{BA}$, and calli formed were transferred to the $\mathrm{N} 6$ medium with $0.1 \mathrm{mg} / l \mathrm{NAA}$ and $5.0 \mathrm{mg} / l \mathrm{BA}$ for plant regeneration.

Some uncertainty has been observed for tetraploid plants.

${ }^{*}$ Five abnormal regenerants were excluded from the Table.

Table 2. Somaclonal variation detected in lines of A2 generation.

\begin{tabular}{|c|c|c|c|c|c|c|}
\hline \multirow[t]{2}{*}{ characteristic } & \multicolumn{2}{|c|}{$\begin{array}{l}\text { one-step } \\
\text { anther culture }\end{array}$} & \multicolumn{2}{|c|}{$\begin{array}{l}\text { two-step } \\
\text { anther culture }\end{array}$} & \multicolumn{2}{|c|}{$\begin{array}{l}\text { protoplast } \\
\text { culture }\end{array}$} \\
\hline & No. & $\%$ & No. & $\%$ & No. & $\%$ \\
\hline lines tested & 13 & 100 & 85 & 100 & 113 & 100 \\
\hline somaclonal variants & 7 & 54 & 58 & 69 & 108 & 96 \\
\hline culm length & 5 & 39 & 37 & 44 & 96 & 85 \\
\hline hair & 2 & 15 & 21 & 25 & 69 & 61 \\
\hline seed fertility & 0 & 0 & 17 & 20 & 31 & 27 \\
\hline panicle length & 0 & 0 & 10 & 12 & 43 & 38 \\
\hline panicle number & 0 & 0 & 6 & 7 & 18 & 16 \\
\hline heading date & 1 & 8 & 3 & 4 & 9 & 8 \\
\hline grain size & 0 & 0 & 1 & 1 & 1 & 1 \\
\hline awn length & 0 & 0 & 1 & 1 & 0 & 0 \\
\hline glume shape & 0 & 0 & 1 & 1 & 0 & 0 \\
\hline
\end{tabular}


number of the lines are available for examination. Nevertheless, it is worthwhile to discuss the results at least semi-quantitatively.

The frequency of somaclonal variation increases with the order of the one-step, the two-step and the protoplast cultures just as was observed for the ploidy of regenerants (Table 2). This supports the previous statement by several authors ${ }^{10-12)}$ that variation increases with increasing duration of culture.

Variations on culm length, hair and heading date are commonly observed in the three cultures with high frequency for the former two and with low frequency for the last one. Variations in seed fertility, panicle length and panicle number are found with relatively low frequency in the two-step anther and the protoplast cultures.

Interestingly, all of these six variations show their specific tendencies in the direction of variation; that is to say, shortening for culm length, reducing to zero for hair, delaying for heading date, lowering for seed fertility, shortening for panicle length, and increasing for panicle number.

The results in Table 2, coupled with these tendencies in the direction allow prediction of the types and frequency of variation to be observed in A2 lines of the anther cultures or the protoplast culture, and help to make effective use of the culture methods for rice breeding.

\section{Some details of variation in the three cell cultures}

\section{(1) Protoplast culture}

More than $95 \%$ of the lines exhibit somaclonal variation, and only 5 lines show no variation in A2 (Table 2 and 3). However, no characteristic variation of protoplast culture is found among the various kind of variants. As for segregation of characteristics, 41 out of 113 lines (36\%) showed segregation in A2. This frequency is almost the same as that observed in the two-step anther culture $^{6}$. From these results, it is concluded that somaclonal variation occurs mainly in the haploid callus rather than homozygous diploid callus in the protoplast culture as well as the anther cultures.

Protoplast culture causes multiple variations in characteristics with high frequency (Table 3). Variation of as many as five characteristics in one plant is found for some lines. It should be, however, noticed that one third of the variants exhibit relatively useful characteristics for rice improvement such as short culm length and reducing hair and that fairly low frequency is observed for unfavorable alteration such as short panicle length and low seed fertility. It is hence understood that variation induced in the protoplast culture does not hinder obtaining useful transformants through protoplast. Table 3 tells at least one useful transformant having advantageous variation can be obtained every three transformants derived through protoplast culture.

Table 3. Multiple variation in A2 lines derived from protoplast culture.

\begin{tabular}{lccll}
\hline $\begin{array}{l}\text { multiplication in } \\
\text { variation } \\
\text { No. }\end{array}$ & \multicolumn{2}{c}{ line } & \multicolumn{2}{c}{ most frequently observed variations } \\
\hline 0 (no variation) & 5 & 5 & & No. \\
1 & $20+6^{* 1}$ & $19+(6)$ & 16 & short culm length \\
2 & 30 & 28 & 18 & short culm length, reducing hair \\
3 & 29 & 27 & 17 & $\begin{array}{l}\text { short culm length, reducing hair, short panicle } \\
\text { length }\end{array}$ \\
4 & 19 & 17 & 9 & $\begin{array}{l}\text { short culm length, reducing hair, short panicle } \\
\text { length, low seed fertility }\end{array}$ \\
5 & 4 & 4 & &
\end{tabular}

${ }^{* 1}$ Variation in one characteristic was detected on reducing hair, low seed fertility or changing heading date. However, whether these six lines had multiple variations or not could not be determined. 


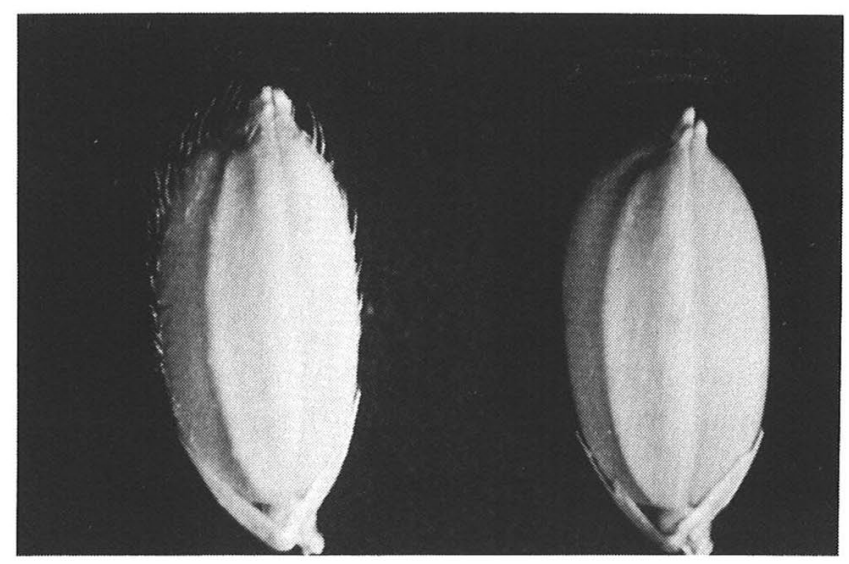

Fig. 1 Somaclonal variation of hair on glume.

Glabrous glume(right) induced by anther culture, and hairy glume(left) of mother cultivar 'Koganebare'.

\section{(2) Anther Culture}

The short duration of the one-step anther culture does not give disadvantageous variations, but does give useful ones for rice improvement such as short culm length and reducing hair (Table 2).

The conventional two-step culture yields the same type of variation with lower frequency than the protoplast culture does(Table 2). Thus, we can obtain any of the variants derived from protoplast culture by the two-step anther culture.

\section{Breeding of glabrous rice plant}

This is the first report, to our knowledge, on somaclonal variation of reducing the hair of rice plants. In fact, the results in this study show a remarkable contrast to those in protoclonal ${ }^{2)}$ and gametoclonal ${ }^{1,13,14)}$ variation studies in which no glabrous variants have been found. Glabrousness is a useful characteristic in rice since dust is drastically reduced in hulling and threshing by machine. This is especially true in this country since most of the popular Japanese rice varieties have hair. This study gives the most reliable method of breeding a glabrous rice variety (Fig. 1). As a matter of fact, a glabrous new variety of 'Sumi-rice' has been bred through the anther culture of 'Koganebare'. The gene locus of glabrousness is now under investigation, and will be published elsewhere.

\section{Acknowledgements}

Authors thank for Dr. H. Oshio and Dr. K. Oeda for their useful discussion and encouragement throughout this study.

\section{References}

1) Wakasa, K., 1982. Bull. Natl. Inst. Agric. Sci., D33: 121-200 (in Japanese).

2) Ogura, H., J. Kyozuka, Y. Hayashi, T. Koba, K. Shimamoto, 1987. Theor. Appl. Genet., 74: 670-676.

3) Chen, Y., 1986. In "Haploids of Higher Plants in Vitro" (eds. by Hu, H., H. Yang), p. 118-136, China Academic Publishers, Beijing.

4) $\mathrm{Hu}, \mathrm{H}$, , 1985. In "Biotechnology in International Agricultural Research", p. 87-96, IRRI, Manila.

5) Sasaki, T., 1985. Japan. J. Breed., 35: 214-215.

6) Yamamoto, T., Y. Soeda, H. Sakano, A. Nishikawa, H. Hirohara, Plant Tissue Culture Letters(submitted). 
7) Toriyama, K., K. Hinata, 1985. Plant Science, 41: 179-183.

8) Ohira, K., K. Ojima, A. Fujiwara, 1973. Plant Cell Physiol., 14: 1113-1121.

9) Chu, C. C., C. C. Wang, C. S. Sun, C. Hsu, K. C. Yin, C. Y. Chu, F. Y. Bi, 1975. Scientica Sinica, 18: 659-668.

10) Barbier, M., H. L. Dulieu, 1983. Plant Sci. Lett., 29: 201-206.

11) Fukui, K., 1983. Theor. Appl. Genet., 65: 225-230.

12) Lorz, H., W. R. Scowcroft, 1983. Theor. Appl. Genet., 66: 67-75.

13) Oono, K., 1975. Bull. Natl. Inst. Agric. Sci., D26: 139-222 (in Japanese).

14) Oono, K., 1978. Trop. Agric. Res. Series, 11: 109-124.

\title{
《和文要約》
}

イネ葯由来の三種の細胞培養法によって得られたソマクロナル変異の系統的解析

\author{
山本俊哉・副田康貴・西川 晶・広原日出男
}

住友化学工業(株)宝塚総合研究所

イネ育種への利用を目指して葯由来の三種の細胞培養法, すなわち葯培養一段階法, 通常の二段階法, プ ロトプラスト培養, で生じるソマクロナル変異について比較しながら系統的に解析した，A 2 世代で見られ たソマクロナル変異の頻度は, 培養期間の長さに比例して葯培養一段階法, 二段階法, プロトプラスト培養 の順に高くなり, プロトプラスト培養では $95 \%$ に達した. 再生植物の倍数性も同様の傾向を示し, プロト プラスト培養では四倍体の割合が $22 \%$ と高かった. 生じたソマクロナル変異の種類は, 三種の培養法とも 稈長と毛性に関するものが普遍的で, 二段階法とプロトプラスト培養では次いで穂数や種子稔性に関するも のが多く見られた．各々のソマクロナル変異は方向性を持っており，たとえば稈長では短秙化，毛性では減 少を示している．また，プロトプラスト培養に特異的な変異は観察されなかった．特筆すべきは，無毛性の ソマクロナル変異が高頻度に生じたことである．無毛性は機械化に適する有用な変異であるが，今までに報 告例がなく, 本研究の結果, 䒺培養あるいはプロトプラスト培養によって無毛性変異が効率よく誘導できる ことがわかった。 